\title{
Carrying Capacity for Pinctada maxima (Jameson 1901) Farming in Sathean Bay, Southeast Maluku Based on Nitrogen and Phosphate Balance
}

\author{
Usman Madubun ${ }^{1}$, Ario Damar ${ }^{2}$, Kadarwan Soewardi ${ }^{2}$, NikenTunjung Murti Pratiwi ${ }^{2}$ \\ ${ }^{1}$ Department of Marine Aquaculture Technology, Tual State Fisheries Polytechnic, Maluku Tenggara, Indonesia \\ Email: umadubun@yahoo.com \\ ${ }^{2}$ Department of Aquatic Resources Management, Bogor Agricultural University, Indonesia
}

\begin{abstract}
Sathean Bay is a small, semi-enclosed waters which have been utilized as an area for pearl oyster farmingusing floating long line method. The growth of pearl oysters are affected by the availability of food (phytoplankton) in the waters. The phytoplankton own self is highly affected by $N$ and $P$ in the waters. This study aims to assess the carrying capacity of the Sathean Bay for pearl oysters farming for three different size group pearl oyster based on the nutrient balance which was the ratio between $N$ and $P$ are available in the waters and in the pearl oyster tissue. The study was conducted from April to September 2016 in nine sampling sites of Sathean Bay, Southeast Maluku. The result showed the smallest group size of pearl oyster $(5 \pm 2 \mathrm{~cm})$ had the highest carrying capacity among the other two size group $(13 \pm 2 \mathrm{~cm}, 18 \pm 2 \mathrm{~cm})$. The carrying capacity of pearl oyster based nitrogen level(DIN) in the waters was always greater than the carrying capacity based on DIP level for all size groups of pearl oyster.
\end{abstract}

Keywords- Pinctada maxima, Sathean Bay, Nitrogen, Phosphate.

\section{INTRODUCTION}

Sathean bay is a small, semi-enclosed waters with an average depth of $22 \mathrm{~m}$ and an average area of $382 \mathrm{ha}$. The bay have been utilized as an area of fisheries, pearl oyster culture, and seaweeds culture (Tomatala 2011; Erbabley \& Kelabora 2014; Ngamel 2012). Pearl oyster culture activities in the bay was carried out using single rope floating (floating long line). Types of cultivated pearl oyster is Pinctada maxima (Jameson 1901) or commercially known as white south sea pearls. Oyster culture using floating long line method is usually built in waters with a depth of 10-30 m (Sutaman 1993). Based on observations, the current long line number are 36 pieces, but can vary according to the needs and availability of seed pearl oysters.
Pearl oyster cultured using a single rope system floating (floating long line) have an impact on the dynamics and processes of aquatic ecosystems. Some of them are, controlling the dynamics of suspended particles, including phytoplankton (Zhou et al. 2006; Tweddle et al. 2005), to divert material suspended from the water column to the food webs benthic through biodeposit feces and pseudofeces (Newell et al. 2005; Newell 2004; Chapelle et al. 2000), and change the dynamics of nutrient waters (Cranford et al. 2003; Newell 2004; Newell et al. 2005; Nizzoli et al. 2005; Metzger et al. 2007).

A low concentration of nutrients in the water column has negative effect on the growth and development of phytoplankton (Damar 2003). On the other hand, the growth of oyster including pearl oysters are affected by the availability of food in the waters, i.e phytoplankton (Anwar et al. 2005; Pouvreau et al. 2000; Yukihira et al. 1999; Rice 2008; Newell et al. 2005; Loret et al. 2000; Winanto 2009; Syda Rao et al. 2009; Hashimoto et al. 2007). Thus, the loss of $\mathrm{N}$ and $\mathrm{P}$ from the water column have a negative impact on the growth of the pearl oysters, as well as excessive amounts of pearl oysters cause a reduction of $\mathrm{N}$ and $\mathrm{P}$ of waters through phytoplankton.

The negative impact of the decline of $\mathrm{N}$ and $\mathrm{P}$ through phytoplankton can be prevented by limiting the loss of $\mathrm{N}$ and $\mathrm{P}$ of waters by limiting and controlling the number of long line oyster pearls used. Restriction and control is conducted by determining the carrying capacity of the waters. Kaiser \& Beadman (2002) defined carrying capacity as the maximum production potential of a species or population that can be supported by related resource availability. Estimation of the carrying capacity of oyster based on resource availability is generally approximated using the availability of phytoplankton or particulate organic matter (POM) in the waters which then compared 
with the needs of oysters (Carver \& Mallet 1990; Karayücel \& Karayücel 1998; Penney et al. 2001).

This study aims to assess the carrying capacity of the Sathean Bay on determining the number of long line and pearl oysters that can be accommodated in a sustainable manner. Carrying capacity was estimated based on the nutrient balance which is the ratio between $\mathrm{N}$ and $\mathrm{P}$ are available in the waters and in the pearl oyster tissue.

\section{METHODS}

\section{Study site}

The study took place in the Sathean Bay, Southeast Maluku, and the study was conducted from April to September 2016 (Figure 1). Water quality parameters measurement and water sampling for nutrient analysis was performed on nine stations. Stations were selected by considering the depth, broad of the bay, and the pearl oysters farming locations. Water quality parameters measured include temperature, salinity, current velocity, $\mathrm{pH}$, and dissolved oxygen. Data obtained by measuring the depth of the bay using a fish finder, while the extents area of the bay was obtained through GIS analysis using Arc GIS software version 10.1. Data of the waters depth and extents of the bay were intended to obtain the waters volume of the bay. Dissolved inorganic nutrients analyzed including nitrate-nitrogen $\left(\mathrm{NO}_{3}-\mathrm{N}, \quad \mathrm{mgL}^{-1}\right), \quad$ nitrite-nitrogen $\left(\mathrm{NO}_{2}-\mathrm{N}, \quad \mathrm{mgL}^{-1}\right)$, ammonium-nitrogen $\left(\mathrm{NH}_{4}-\mathrm{N}, \mathrm{mg} \mathrm{L}^{-1}\right)$, and orthophosphate $\left(\mathrm{PO}_{4}-\mathrm{P}, \mathrm{mgL}^{-1}\right)$. Water sampling, preservation, transportation, and sample analysis were performed by standard methods from Standard Methods for the Examination of Water and Wastewater (APHA 2005).

Pearl oyster used in the study were grouped into three size classes of shell length (Dorso Ventral, DV), i. e $5 \pm 2 \mathrm{~cm}$, $13 \pm 2 \mathrm{~cm}$, and $18 \pm 2 \mathrm{~cm}$. The oysters were obtained from Sathean Bay. All of the pearl oyster shell used were cleaned from the attacks organisms, the pearl oyster weight (BW, g) was measured using digital scaleto the nearest $0.1 \mathrm{~g}$, then the total shell length $(\mathrm{mm})$, total shell width $(\mathrm{mm})$, and the shell thickness $(\mathrm{mm})$ was measured using caliper and ruler. Thirteen pearl oysters with size range $3 \mathrm{~cm}$ to $18 \mathrm{~cm}$ of a shell height were collected for the meat (DW, g) and shell (DW, g) dry weight analysis which was dried at $105^{\circ} \mathrm{C}$ for 24 hours. In addition, others supporting data were also collected such as the total number of pearl oyster and number of pearl oyster per basket in the current culture, the number of baskets per long line, long line length, the distance between long line, and the growth of pearl oysters.

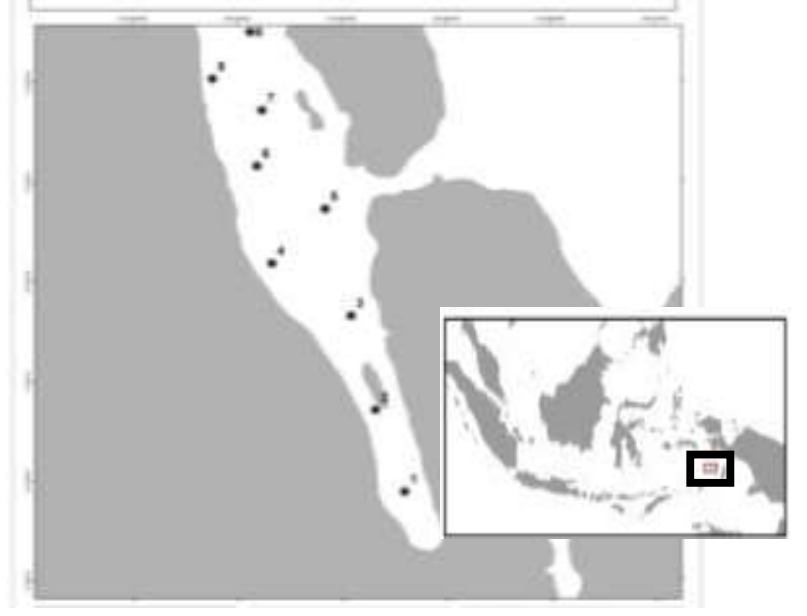

Fig.1: Study site

\section{Data Analysis}

Estimation of the DIN and DIP needs of pearl oyster

Prediction of TN and TP levels in pearl oysters using a value which was defined by Gifford et al. (2005), namely, the nitrogen content in meat and shells of pearl oyster were $\mathrm{g}^{-1} \mathrm{DW} 9.82 \%$ and $0.39 \% \mathrm{~g}^{-1} \mathrm{DW}$. Phosphorus levels in meat and shells of pearl oyster are $\mathrm{g}^{-1} \mathrm{DW} 0.74 \%$ and $0.03 \%$ $\mathrm{g}^{-1} \mathrm{DW}$, respectively. Referring to these values, the levels of $\mathrm{N}$ and $\mathrm{P}$ per individual of each group size of pearl oyster is calculated as follows:

$\mathrm{TN}_{\mathrm{tm}}=(\mathrm{A} \cdot 9,82 \%)+(\mathrm{B} \cdot 0,39 \%)$

$\mathrm{TP}_{\mathrm{tm}}=(\mathrm{A} \cdot 0,74 \%)+(\mathrm{B} \cdot 0,03 \%)$

Where:

$\mathrm{TN}_{\mathrm{tm}}$ and $\mathrm{TP}_{\mathrm{tm}} \quad=\mathrm{N}$ and $\mathrm{P}$ needs of pearl oyster according to group sizes $(\mathrm{g})$

$\mathrm{A}$ and $\mathrm{B} \quad=$ dry weight of the meat and shell pearl oyster of one individual of each class sizes $(\mathrm{g})$

$9,82 \%$ and $0,74 \%=$ fraction of $\mathrm{N}$ and $\mathrm{P}$ content per $\mathrm{g}$ DW pearl oyster meat

$0,39 \%$ and $0,03 \%=$ fraction of $\mathrm{N}$ and $\mathrm{P}$ content per $\mathrm{g}$ DW pearl oyster shell

Forms of nutrients that were used in this analysis were DIN and DIP. Pearl oyster nutrient levels in the form of TN and TP $\left(\mathrm{gg}_{-1} \mathrm{DW}\right)$ need to be converted to the form of DIN and DIP. To convert TN and TP to DIN and DIP we used Diego-McGlone et al. (2000) approach, where DIN $=0.38 \mathrm{x}$ $\mathrm{TN}$ and DIP $=0.5 \times \mathrm{TP}$. DIN is the summation of nitrogen form $\mathrm{NH}_{4}, \mathrm{NO}_{2}$ and $\mathrm{NO}_{3}$. Whereas DIP consisting only of $\mathrm{PO}_{4}$. DIP $\mathrm{tm}_{\mathrm{tm}}$ and $\mathrm{DIN}_{\mathrm{tm}}$ value were pearl oysters parameters nutrient needs which was used in assessing the carrying 
capacity of the waters for the development of pearl oyster culture in this approach.

\section{Estimation of availability of DIN and DIP in Waters}

To determine the availability of dissolved inorganic $\mathrm{N}$ and $\mathrm{P}$ in the waters of the bay, we need the data of the concentration of $\mathrm{N}\left(\mathrm{NH}_{4}-\mathrm{N}, \mathrm{NO}_{3}-\mathrm{N}, \mathrm{NO}_{2}-\mathrm{N}\right)$ and $\mathrm{P}\left(\mathrm{PO}_{4}-\mathrm{P}\right)$ in water $\left(\mathrm{N}_{\text {water }}\right.$ and $\left.\mathrm{P}_{\text {water }}\right)$ and the volume of waters bay (Vo). $\mathrm{N}_{\text {water }}$ and $\mathrm{P}_{\text {water }}$ value were obtained from the analysis of water samples in the laboratory, which produce unit $\mathrm{mgL}^{-1}$. This unit needs to be converted to $\mathrm{gL}^{-1}$ to facilitate further calculations. By applying the precautionary principle in order to avoid over-estimation, the value $\mathrm{N}_{\text {water }}$ and $\mathrm{P}_{\text {water }}$ used in the calculation were the lowest one that measured during the study. Then $\mathrm{N}_{\text {water }}$ and $\mathrm{P}_{\text {water }}$ value were then converted to DIN water $_{\text {and }}$ DIP water $_{\text {(Diego-McGlone et }}$ al. 2000). Value of DIN water $_{\text {and }}$ DIP $_{\text {water }}$ in total over the whole bay waters were calculated by the equation:

$\operatorname{DIN}_{\text {water-tot }}(\mathrm{g}) \quad=\mathrm{N}_{\text {air }} \cdot \mathrm{Vo}$

$\operatorname{DIP}_{\text {water-tot }}(\mathrm{g}) \quad=\mathrm{P}_{\text {air }} \bullet \mathrm{Vo}$

Where:

DIN $_{\text {water-tot }} \&$ DIP $_{\text {water-tot }}=$ the total amount of $\mathrm{N}$ and $\mathrm{P}$ in the waters of the bay $(\mathrm{g})$

$\mathrm{DIN}_{\text {water }} \& \mathrm{DIP}_{\text {water }} \quad=\mathrm{N}$ and $\mathrm{P}$ concentrations in water samples $\left(\mathrm{gL}^{-1}\right)$

$\mathrm{Vo}=$ total volume waters of the bay $(\mathrm{L})$

The volume of water in the bay $\left(\mathrm{Vo}, \mathrm{m}^{3}\right)$ was calculated according to the formula Beveridge (2004):

$\mathrm{Vo}_{\mathrm{o}}=\mathrm{A} \cdot \mathrm{D}$

Where:

$$
\begin{aligned}
& \mathrm{Vo}=\text { waters volume of the bay }\left(\mathrm{m}^{3}\right) \\
& \mathrm{A}=\text { the surface area of the bay }\left(\mathrm{m}^{2}\right) \\
& \mathrm{D}=\text { The average depth of the bay }(\mathrm{m})
\end{aligned}
$$

Vo unit converted to liters by multiplying $10^{-3}$. The surface area of the bay was calculated using GIS. The average depth of the bay waters known through bathymetric measurements.

However, not all DIN water-tot $_{\text {and }}$ DIP water-tot $_{\text {taken by pearl }}$ oysters. Based on research Gifford et al. (2005), the amount of nutrients flowing into the body of the pearl oyster is only approximately $2.0 \% \mathrm{~N}$ and $0.2 \% \mathrm{P}$ of $\mathrm{N}$ and $\mathrm{P}$ in the waters. This figures were used as a correction factor retrieval capability of $\mathrm{N}$ and $\mathrm{P}$ by pearl oyster of $\mathrm{N}$ and $\mathrm{P}$ which are available in the waters. Thus, DIN and DIP which are available in total over the bay waters that can be used by the oyster was:

$$
\begin{aligned}
& \operatorname{DIN}_{\text {available }}(\mathrm{g})=\operatorname{DIN}_{\text {water-tot }} \cdot 2,0 \% \\
& \operatorname{DIP}_{\text {available }}(\mathrm{g})=\operatorname{DIP}_{\text {water-tot }} \bullet 0,2 \%
\end{aligned}
$$

Where:

$$
\begin{aligned}
& \text { DIN }_{\text {available }} \text { and DIP } P_{\text {available }}=\text { DIN and DIP which available } \\
& \text { for oysters }(\mathrm{g}) \\
& \text { DIN }_{\text {water-tot }} \text { and DIP } \text { water-tot }=\text { total availability of DIN and } \\
& \text { DIP in the waters of the bay } \\
& \text { (g) } \\
& 2,0 \% \text { and } 0,2 \% \\
& \text { = retrieval capability of } \mathrm{N} \text { and } \mathrm{P} \\
& \text { by pearl oyster from the } \\
& \text { waters. }
\end{aligned}
$$

DIN $_{\text {available }}$ and DIP available are the value of nutrient availability parameter that will be used in the estimation of the carrying capacity of the nutrient balance approach developed in this study.

\section{Analysis of Carrying Capacity for pearl oysters culture}

Estimation of the carrying capacity of sustainable oyster pearl culture based on nutrient ( $\mathrm{N}$ and $\mathrm{P}$ ) balance was performed separately for each group size as follows:

$\begin{aligned} \mathrm{DD}_{\mathrm{L}-\mathrm{tm}} \mathrm{DIN} & =\mathrm{DIN}_{\text {available }} / \mathrm{DIN}_{\mathrm{tm}} \\ \mathrm{DD}_{\mathrm{L}-\mathrm{tm}} \mathrm{DIP} & =\mathrm{DIP}_{\text {available }} / \mathrm{DIP}_{\mathrm{tm}}\end{aligned}$

Where:

$\mathrm{DD}_{\mathrm{L}-\mathrm{tm}} \mathrm{DIN} \& \mathrm{DD}_{\mathrm{L}-\mathrm{tm}} \mathrm{DIP}=$ Sustainable carrying capacity of pearl oysters based on DIN and DIP according to the size (number of individual)

DIN $_{\text {available }}$ \& DIP available $=$ DIN and DIP which are available for oysters $(\mathrm{g})$

$\mathrm{DIN}_{\mathrm{tm}} \& \mathrm{DIP}_{\mathrm{tm}} \quad=$ DIN and DIP oysters needs according to the size $(\mathrm{g})$

Then, if each one long line consisting of $\mathrm{E}$ (individual) pearl oyster according group sizes, the numbers of long line possible are:

$\mathrm{nL}=\mathrm{DD}_{\mathrm{L}-\mathrm{tm}} / \mathrm{E}$

and the effective broad water area (ha) that can be used as a pearl oyster farming using long line method is:

waters area $(\mathrm{ha})=\mathrm{nL} \cdot 1$ unit size $/ 10.000$

by $\mathrm{nL}$ is the number of long line permitted, and 10,000 are convertion value into hectares (ha). 
III.

RESULT

Waters volume of Sathean Bay

Tides Type in the Sathean Bay was semi diurnal with the maximum daily tidal differences was $2.6 \mathrm{~m}$ (Figure 2). The surface area and volume of the bay waters at various water level was shown in Table 1.

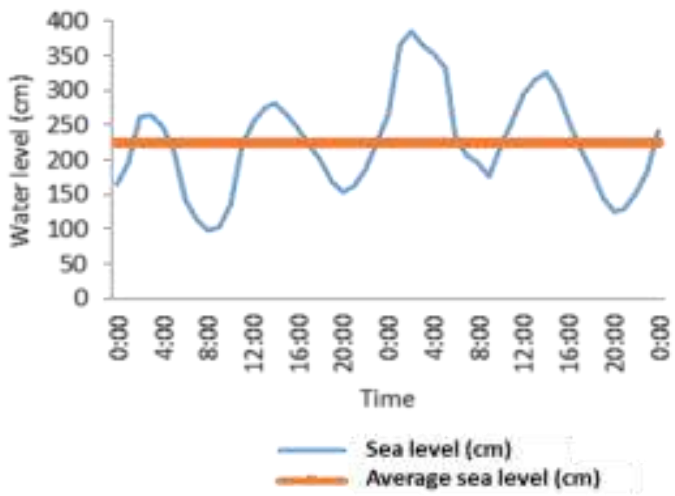

Fig.2: Type and duration of the tides in the Sathean bay measured at spring tide

Table.1: Volume of Sathean Bay waters at different water level

\begin{tabular}{ccccc}
\hline Tides & $\begin{array}{c}\text { Tidal range } \\
(\mathrm{m})\end{array}$ & $\begin{array}{c}\text { MSL water level } \\
(\mathrm{m})\end{array}$ & $\begin{array}{c}\text { Surface area of the bay } \\
\left(\mathrm{m}^{3}\right)\end{array}$ & $\begin{array}{c}\text { Waters volume of the bay } \\
(\mathrm{L})\end{array}$ \\
\hline MHWS & 2.6 & 1.3 & $3,758,132$ & $84.951 .099,41$ \\
MLWS & \multirow{2}{*}{2.3} & $3,470,249$ & $75,179,956.21$ \\
\hline Volume mean & & & 80.051 .165 & 80.051 .164 .940 \\
\hline
\end{tabular}

MHWS: Mean High Water Spring

MLWS: Mean Low Water Spring

\section{$\mathbf{N}$ and $\mathbf{P}$ Needs of pearl oyster}

Dry weight (DW) of the meat and shell of pearl oyster from the three size groups were listed in Table 2 , while the levels of DIN and DIP were shown in Table 3.

Table.2: The mean and percentage of dry weight of the pearl oyster according to group sizes

\begin{tabular}{|c|c|c|c|c|c|c|c|c|c|c|c|c|}
\hline \multirow[t]{2}{*}{ No } & \multirow{2}{*}{$\begin{array}{c}\text { Size groups } \\
\mathrm{cm}\end{array}$} & \multirow{2}{*}{$\begin{array}{c}\text { height } \\
\mathrm{cm}\end{array}$} & \multirow{2}{*}{$\begin{array}{c}\text { wide } \\
\mathrm{cm}\end{array}$} & \multirow{2}{*}{$\begin{array}{c}\begin{array}{c}\text { Total wet } \\
\text { weight }\end{array} \\
\mathrm{g}\end{array}$} & \multicolumn{2}{|c|}{$\begin{array}{c}\text { Meat wet } \\
\text { weight }\end{array}$} & \multicolumn{2}{|c|}{$\begin{array}{c}\text { Meat dry } \\
\text { weight }\end{array}$} & \multicolumn{2}{|c|}{$\begin{array}{c}\text { Shell wet } \\
\text { weight }\end{array}$} & \multicolumn{2}{|c|}{ Shell dry weight } \\
\hline & & & & & $\mathrm{g}$ & $\%$ & $\mathrm{~g}$ & $\%$ & $\mathrm{~g}$ & $\%$ & $\mathrm{~g}$ & $\%$ \\
\hline 1 & $5 \pm 2$ & 4,3 & 4,5 & 9,1 & 1,6 & 18,0 & 0,3 & 19,1 & 7,5 & 82,0 & 8,0 & 92,9 \\
\hline 2 & $13 \pm 2$ & 13,8 & 13,0 & 253,5 & 46,0 & 18,1 & 10,7 & 23,2 & 207,5 & 81,9 & 192,4 & 92,7 \\
\hline 3 & $18 \pm 2$ & 17,4 & 15,4 & 657,0 & 86,0 & 13,1 & 19,9 & 23,1 & 571,0 & 86,9 & 560,9 & 98,2 \\
\hline
\end{tabular}

Table.3: The mean levels of DIN and DIP $\left(\mathrm{gg}^{-1} \mathrm{DW}\right)$ of meat and shell of pearl oysters in the Sathean Bay in various group sizes

\begin{tabular}{|c|c|c|c|c|c|c|c|}
\hline \multirow{2}{*}{ No } & \multirow{2}{*}{$\begin{array}{l}\text { Size groups } \\
(\mathrm{cm})\end{array}$} & \multicolumn{2}{|c|}{ Meat (g) } & \multicolumn{2}{|c|}{ Shell (g) } & \multicolumn{2}{|c|}{ Total } \\
\hline & & DIN & DIP & DIN & DIP & DIN & DIP \\
\hline 1 & $5 \pm 2$ & 0,013 & 0,001 & 0,011 & 0,001 & 0,023 & 0,002 \\
\hline 2 & $13 \pm 2$ & 0,400 & 0,040 & 0,263 & 0,029 & 0,663 & 0,069 \\
\hline 3 & $18 \pm 2$ & 0,743 & 0,074 & 0,766 & 0,084 & 1,509 & 0,158 \\
\hline
\end{tabular}

\section{Availability of DIN and DIP in Water}


Minimal concentration of DIN and DIP in the waters was presented in Table 4, while Table $\mathbf{5}$ contained the maximum number of DIN and DIP which were available for pearl oysters.

Table.4: Minimal concentration of DIN and DIP in the Sathean Bay

\begin{tabular}{cccc}
\hline No & Parameter & Unit & Value \\
\hline 1 & $\mathrm{NH}_{4}$ & $\mathrm{mgL}^{-1}$ & 0,048 \\
2 & $\mathrm{NO}_{2}$ & $\mathrm{mgL}^{-1}$ & 0,003 \\
3 & $\mathrm{NO}_{3}$ & $\mathrm{mgL}^{-1}$ & 0,023 \\
4 & $\mathrm{PO}_{4}$ & $\mathrm{mgL}^{-1}$ & 0,003 \\
5 & $\mathrm{DIN}$ & $\mathrm{mgL}^{-1}$ & 0,074 \\
6 & $\mathrm{DIP}$ & $\mathrm{mgL}^{-1}$ & 0,003 \\
\hline
\end{tabular}

Table.5: The concentration of DIN and DIP available in the waters which can be utilized by oysters in the Sathean Bay

\begin{tabular}{ccccc}
\hline No & $\begin{array}{c}\text { Nutrient } \\
\text { type }\end{array}$ & $\begin{array}{c}\text { Minimal concentration } \\
(\mathrm{mg} / \mathrm{L})\end{array}$ & Waters volume $(\mathrm{L})$ & $\begin{array}{c}\text { Total nutrient in water }(\mathrm{g}) \\
\text { Available } \\
\text { nutrient }(\mathrm{g})\end{array}$ \\
\hline 1 & DIN & 0,074 & 80.128 .050 .840 & 5.934 .216 \\
2 & DIP & 0,003 & 80.128 .050 .840 & 240.384 \\
\hline
\end{tabular}

\section{Carrying capacity of pearl oysters farming}

Number of pearl oysters that can be accommodated in Sathean Bay waters according to group sizes and types of nutrients was shown in Table 6. Number of long line of pearl oyster and effective waters area for pearl oysters farming were presented in

Table 7 and Table 8.

Table.6: Carrying capacity of the Sathean Bay waters for pearl oyster farming based on nutrient availability approach

\begin{tabular}{cccccccc}
\hline \multirow{2}{*}{ No } & Size group $(\mathrm{cm})$ & \multicolumn{2}{c}{ Available nutrient $(\mathrm{g})$} & \multicolumn{2}{c}{ Nutrient needs of oyster $(\mathrm{g})$} & \multicolumn{2}{c}{ DDL_TM } \\
\cline { 3 - 7 } & & DIN & DIP & DIN & DIP & DIN & DIP \\
\hline 1 & $5 \pm 2$ & $118.684,3$ & $6.410,2$ & 0,023 & 0,002 & 5.060 .838 & 2.624 .541 \\
2 & $13 \pm 2$ & $118.684,3$ & $6.410,2$ & 0,663 & 0,069 & 179.127 & 7.017 \\
3 & $18 \pm 2$ & $118.684,3$ & $6.410,2$ & 1,509 & 0,158 & 78.651 & 3.046 \\
\hline
\end{tabular}

DDL_TM = Carrying capacity for pearl oyster in number of pearl oyster (individual)

Table.7: Number of long line for pearl oyster farming according to group sizes

\begin{tabular}{|c|c|c|c|c|c|c|}
\hline \multirow[t]{2}{*}{ No } & \multirow[t]{2}{*}{ Size group } & \multicolumn{2}{|c|}{ DDL_TM } & \multirow{2}{*}{$\begin{array}{c}\text { Number of } \\
\text { oyster/long line }\end{array}$} & \multicolumn{2}{|c|}{ Number of long line } \\
\hline & & DIN & DIP & & DIN & DIP \\
\hline 1 & $5 \pm 2$ & 5.060 .838 & 2.624 .541 & 4.800 & 1.054 & 41 \\
\hline 2 & $13 \pm 2$ & 179.127 & 93.558 & 2.000 & 90 & 4 \\
\hline 3 & $18 \pm 2$ & 78.651 & 40.612 & 1.600 & 49 & 2 \\
\hline
\end{tabular}

Table.8: Water area effective for pearl oysters in the bay Sathean

\begin{tabular}{|c|c|c|c|c|c|c|}
\hline \multirow{2}{*}{ No } & \multirow{2}{*}{ Size group } & \multicolumn{2}{|c|}{ Number of long line } & \multirow{2}{*}{$\begin{array}{l}\text { Broad of } 1 \text { unit } \\
\text { pearl oyster } \\
\text { culture }\end{array}$} & \multicolumn{2}{|c|}{ Total area (ha) } \\
\hline & & DIN & DIP & & DIN & DIP \\
\hline 1 & $5 \pm 2$ & 1.014 & 547 & 0,5 & 507 & 21 \\
\hline 2 & $13 \pm 2$ & 87 & 47 & & 43 & 2 \\
\hline 3 & $18 \pm 2$ & 47 & 25 & & 24 & 1 \\
\hline
\end{tabular}

\section{DISCUSSION}

Hidromorphology bay and Water Quality Parameters
Sathean bay is a small bay, semi-enclosed, yet deep enough. Waters inside the bay is connected with the waters outside 
the bay through two doors, the first located in the northern part of the bay, the second door on the eastern side of the bay. At low tide, the second door was completely dry. Thus the exchange of water was much more smoothly on the first door. Tides type of bay was semi diurnal with the tide range was $2.60 \mathrm{~m}$. Average depth of the bay was $21.66 \mathrm{~m}$, the surface area of 347.02 ha bay at low tide, while the high tide was 375.81 ha. At high tide the water volume amounted to $84,936,736,540 \mathrm{~L}$ and at low tide was $75,165,593,340 \mathrm{~L}$. Water quality parameters such as temperature, salinity, dissolved oxygen, and current velocity observed were not greatly fluctuated both among stations and month (Table 2). This happens allegedly due to the time of the observations were only conducted in the transition season and in the east monsoon, so that the effect of seasonal changes was not detected. Despite the bay are also relatively small, and the fresh water input through the river are absent. This condition causes the waters of the bay is in relatively homogeneous condition. All the parameters of the water quality does not vary much with the results of research from elsewhere (Hamzah \& Nababan 2011; Gervis \& Sims, 1992; Anwar 2005; Winanto et al. 2009). Overall the quality parameter Sathean Gulf waters are still suitable for the life and growth of pearl oysters (Winanto 2009).

\section{Levels of $\mathbf{N}$ and $\mathbf{P}$ in pearl oysters and Bodies}

The percentage of fresh weight and dry weight of meat and shell pearl oyster of third size group does not vary much (Table 2). Meat percentage wet weight of total body weight size group of $18 \pm 2 \mathrm{~cm}$ smaller (13.1\%) compared two groups of other sizes (18.0 and $18.1 \%$ ). Percentage of dry weight of the meat on a size group of $5 \pm 2 \mathrm{~cm}$ relatively smaller than the two larger size. The percentage weight of the wet shell was greater in size group of $18 \pm 2 \mathrm{~cm}$ from the two groups of other sizes. Percentage of the shell dry weight was relatively similar between the two groups of smaller but less than size group of $18 \pm 2 \mathrm{~cm}$.

Both levels of DIN and DIP were higher in meat than in the shell. In the pearl oyster meat, DIN and DIP highest levels found in oysters the size of $18 \pm 2 \mathrm{~cm}$ and the smallest class size of $5 \pm 2 \mathrm{~cm}$ (Table 3). The same pattern also applies to DIN and DIP in pearl oyster shells. This is reasonable considering the percentage of $\mathrm{N}$ and $\mathrm{P}$ per gram dry weight relatively constant, but the weight of individual increases with increasing height dimension. Thus the real value will depend on the dry weight of the pearl oyster.

Minimal concentration of $\mathrm{NH}_{4}, \mathrm{NO}_{3}, \mathrm{NO}_{2}$, and $\mathrm{PO}_{4}$ respectively measured at the station and at different times (Table 4). Minimal concentration of $\mathrm{NH}_{4}\left(0,048 \mathrm{mgL}^{-1}\right)$ measured at 4 station in September. The concentration of
$\mathrm{NO}_{3}$ minimal $\left(0,023 \quad \mathrm{mgL}^{-1}\right)$ detected at station 7 September, $\mathrm{NO}_{2}$ minimal $\left(0,003 \mathrm{mgL}^{-1}\right)$ measured at station 3 in April, and $\mathrm{PO}_{4}$ minimal $\left(0,040 \mathrm{mgL}^{-1}\right)$ at almost all stations in May and June. Based on the sum of all forms of nitrogen, obtained DIN amounted to $0,074 \mathrm{mgL}^{-1}$, whereas DIP is only represented by $\mathrm{PO}_{4}$ was $0.04 \mathrm{mgL}^{-1}$. The ratio DIN/DIP was 2.

The surface area of the bay was varied over high tide and low tide, so the average volume of the low tide and high tide was used in the calculation of total DIN and DIP in the bay waters. Waters volume in high tide was obtained from waters volume in low tide added with the multiplication of daily tidal differences $(2.6 \mathrm{~m})$ and surface area in high tide. The amount of DIN available in the waters and ready to be used by the pearl oyster was almost 19 times higher than the amount of DIP. The amount of DIN in the water volume in Secchi depth was $5928522 \mathrm{~g}$, which was beyond two times higher than DIP (3 $202047 \mathrm{~g}$ ) (Table 5). However, the amount of nutrient which actually available in waters and can be utilized by the pearl oyster was $118570 \mathrm{~g}$ fir DIN and $6404 \mathrm{~g}$ for DIP.

\section{Carrying Capacity of Pearl Oysters}

The numbers of pearl oysters which can be accommodated in the Sathean Bay waters differ, both based on the nutrient type (DIN and DIP) and among different size group (Table 6). According to nutrient type, the amount of oyster based on DIN (5 055982 individual) was almost two times higher than the one based on DIP (2 622023 individual). Based on the size, the two of the larger size group only numbered $4 \%$ and $2 \%$ respectively of the individual smallest size group.

In general, the number of long line based on DIN level that can be accommodated by Sathean Bay was almost twice higher than DIP-based long line for all group sizes of pearl oysters (Table 7). The number of long line of the smallest group size oyster based on DIN level was 1053 unit, the second group size maximum number of long line was 89 , and the larger group size had the maximum number of long line was 49 unit. Meanwhile, based on DIP, the maximum number of long line from the smallest size group to the largest were 546, 47, and 25 unit respectively.

The total area (ha) needed to accommodate the maximum number of long line was different nearly two times between the calculation based on DIN and DIP (Table 8). Based on DIN level, total area to maintain pearl oyster farming were 507,43 , and 24 ha respectively for the smallest group size oysters to the largest. While based on DIP, total area required for smallest to the largest class sizes of pearl oyster were 273, 23, and 13 ha, respectively. From the data that 
has been presented, the larger the size of the pearl oyster, the fewer the number of individuals that was can be accommodated, so the fewer the number of long line and effective land that were used.

Compared to the existing condition, the size of the oysters which had been cultured currently were 11-15 cm oyster size with a total number of 72000 individuals $(77.4 \%$ of carrying capacity of $13 \pm 2 \mathrm{~cm}$ oyster size), 36 long line (77.0\% of the carrying capacity) and 18 ha (78.3\% of the carrying capacity) of waters area used for oyster culture. Thus, the existing number of individuals oysters, number of long line units, and waters area used for oyster cultured were not exceed the carrying capacity yet. However, it almost reached the calculated carrying capacity based on $\mathrm{N}$ and $\mathrm{P}$ balance.

\section{Carrying Capacity of Maintenance Unit Accordance Carrying Capacity of Sathean Bay}

There are differences between the carrying capacity results based on DIN and DIP which the carrying capacity based on the DIN was almost 200\% higher than the other one based on DIP. To avoid over-estimation, the lower result based on DIP calculation was used as the carrying capacity for pearl oyster culture in Sathean Bay. The results calculations of the carrying capacity (Table 6, 7, and 8) was conducted on a size group of oysters separately, in other words, not as a size group that was cultured continuously. This result was a reference which number of pearl oyster should not be exceed it. Therefore, if the pearl oyster will be cultured continuously until it reaches the desired size with the greatest number of oyster appropriate the carrying capacity, the number of initial stocking needs to be calculated by taking into account mortality rates.

The mortality rates differ according to size groups of oysters. The oyster with the size group of 3-7 cm was $80 \%$, the size of $7-15 \mathrm{~cm}$ by about $30 \%$, and $>15 \mathrm{~cm}$ was $30 \%$. If the final number of pearl oysters measuring $18 \pm 2 \mathrm{~cm}$ is desired in accordance with the carrying capacity based DIP which were 40573 individual, the initial stocking density of oysters with the size of $3 \mathrm{~cm}$ should be as many as 414010 individual, requires long line as many as 86 units and an area of $43 \mathrm{ha}$. At the end of the rearing period of this size $(7-8 \mathrm{~cm})$ will be left over 82802 individual. Further cultivation until reach the size of $15 \mathrm{~cm}$ will be left as many as 57961 individual, requires 29 long line and needs waters area of 14 ha. Further cultivation until reach $20 \mathrm{~cm}$ in size will be left were 40573 individuals with long line 25 units and needs an area of 13 ha. Both the number of oysters, long line, and waters area of the oyster size less than $15 \mathrm{~cm}$, have not exceeded carrying capacity of each size according to this result calculation. While pearl oyster size of $20 \mathrm{~cm}$ have a corresponding individuals number of carrying capacity planned.

\section{CONCLUSION}

The current pearl oysters culture in Sathean Bay has not exceeded the carrying capacity based on $\mathrm{N}$ and $\mathrm{P}$ nutrients yet. However, the existing conditions including number of oysters, long line, and the total are generally has exceed $77 \%$ of the carrying capacity. Therefore, the expansion of the pearl oyster culture should be conducted carefully and meticulously.

\section{REFERENCES}

[1] Anwar K. 2005. Studi Patterns of Reproduction and Maintenance of Pearl Oyster Larvae (Pinctada maxima Jameson) on Natural Feeding. [disertation]. Bogor (ID): Bogor Agricultural University.

[2] [APHA] American Public Health Association. 1998. Standard Methods for the Examinition of Water and Wastewater. Ed ke-20. Washington (ED): Amer.Publ. Health Association Inc. xxxvii + 1112 hal.

[3] Beveridge MCM. 2004. Cage Aquaculture. 3rd Edition. Blackwell Publishing, Oxford, UK. 368 p. Bolte J, Nath S, Ernst D. 2000. Development of decision support tools for aquaculture: the POND experience. Aquacultural Engineering. 23(1):103-119.

[4] Carver CEA, Mallet AL. Estimating the carrying capacity of a coastal inlet for mussel culture. Aquaculture. 88: 39-53.

[5] Chapelle A, Ménesguen A, Deslous-Paoli J-M, Souchu P, Mazouni N, Vaquer A, Millet B. 2000. Modelling nitrogen, primary production and oxygen in a Mediterranean lagoon. Impact of oysters farming and inputs from the watershed. Ecological Modelling. 127 (2-3) : 161-181.

[6] Cranford P, Dowd M, Grant J, Hargrave B, McGladdery S. 2003. Ecosystem level effects of marine bivalve aquaculture. In A scientific Review of the potential environmental effects of aquaculture in aquatic ecosystems. Can. Tech. Rep. Fish. Aquat. Sci.

[7] Damar A. 2003. Effects of enrichment on nutrient dynamics, phytoplankton dynamics and productivity in Indonesian waters: a comparison between Jakarta Bay, Lampung Bay and Semangka Bay [disertasi]. Kiel. Christian Albrechts University. xi +236 hal.

[8] Diego-McGlone M, Smith SV, Nicolas VF. 2000. Stoichiometric interpretations of $\mathrm{C}: \mathrm{N}: \mathrm{P}$ ratios in 
organic waste material. Marine Pollution Bulletin. 40 (4): 325-330.

[9] Erbabley NYGF, Kelabora DM. 2014. Somatic growth rate of Kappaphycus alvarezii in Sathean Vilage Kei Kecil Distrik South East Maluku. Journal Omni Akuatika. 13 (19): 25-33. DOI: http://dx.doi.org/10.20884/1.oa.2014.10.1.13

[10] Gervis MH, Sims NA. 1992. The biology and culture of pearl oysters (Bivalvia: Pteriidae). Philippines (ED): ICLARM Stud. Rev. 21, 49 p.

[11] Gifford S, Dunstan H, O'Connor, Macfarlane GR. 2005. Quantification of in situ nutrient and heavy metal remediation by small pearl oyster (Pinctada imbricata) farm at Port Stephens, Australia. Marine Pollution Bulletin. 50: 417-422. Doi:10.1016/j.marpolbul.2004.11.024.

[12] Hamzah MS, Nababan B. 2011. Influence of Season and Depth ofGrowth and Survival Rate of Pearl Mussels (pinctada maxima) in Kodek Bay, Lombok Utara. Journal Tropical Marine Science and Technology, 3 (2): 48-61.

[13]Hart AM, Thomson AW, Murphy D. 2011. Environmental influences on stok abundance and fishing power in the silver-lipped pearl oyster fishery. ICES Journal of Marine Science 68: 444-453. Doi:10.1093/icesjms/fsq166.

[14] Hashimoto T, Hyodo K, Hirose T, Nishikawa S, Katano T, Nakano S. 2007. Evaluation of three phytoplankton species as food for the pearl oyster Pinctada fucata. Aquacult Int. DOI 10.1007/s10499007-9144-8.

[15] Kaiser MJ, Beadman HA. 2002. Scoping study of the carrying capacity for bivalve cultivation in the coastal waters of Great Britain. The Crown Estate. Interim Report, 39pp.

[16] Karayücel S, Karayücel I. 1998. Estimating the carrying capacity of Mussel raft system in two Scottish sea lochs. The Israeli Journal of Aquaculture. 50 (1): 12-19.

[17] Loret P, Pastoureaud A, Bacher C, Delesallel B. 2000. Phytoplankton composition and selective feeding of the pearl oyster Pinctada margaritifera in the Takapoto lagoon (French Polynesia): in situ study using optical microscopy and HPLC pigment analysis. Mar Ecol Prog Ser.199:55-67.

[18] Metzger E, Simonucci C, Viollier E, Sarazin G, Pre'vot F, Je'ze'quel D. 2007. Benthic response to shellfish farming in Thau lagoon: Pore water signature. Estuarine, Coastal and Shelf Science 72: 406-419

[19] Newell RIE. 2004. Ecosystem influences of natural and cultivated populations of suspension-feeding bivalve molluscs: A review. Journal ofShelfish Research. 23 (1) 51-61.

[20] Newell RIE, Fisher TR, Holyoke RR, Cornwell JC. 2005. Influence of Eastern Oysters on Nitrogen and Phosphorus Regeneration in Chesapeake Bay, USA. Pages 93 - 120. In: The Comparative Roles of Suspension Feeders in Ecosystems. R. Dame and S.Olenin, eds. Vol. 47, NATO Science Series: IV Earth and Environmental Sciences. Springer, Netherlands.

[21] Ngamel AK. 2012. Financial Analysis of Seaweed Farming and Value-Added FlourCarrageenan in Kei Kecil Districts, Southeast Maluku. Journal Applied Sciences. 2 (1): 68-83.

[22] Nizzoli D, Welsh DT, Bartoli M, Viaroli P. 2005. Impacts of mussel (Mytilus galloprovincialis) farming on oxygen consumption and nutrient recycling in a eutrophic coastal lagoon. [Abstrac]. Hydrobiologia. 550 (1): 183-198. DOI 10.1007/s10750-005-4378-9.

[23]Penney RW, McKenzie CH, Mills TJ. 2001. Assessment of the particulate food supply available for Mussel (Mytilus spp.) farming in a semi-enclosed, Northern Inlet. Estuarine, Coastal and Shelf Science. 53, 107-121. doi:10.1006/ecss.2001.0783

[24] Pouvreau S, Bacher C, He'ral M. 2000. Ecophysiological model of growth and reproduction of the black pearl oyster, Pinctada margaritifera: potential applications for pearl farming in French Polynesia. Aquaculture. 186: 117-144.

[25] Sudewi, Supii AI, Sutarmat T, Yudha HT. 2010. Separating Oyster Pearl, Pinctada maxima with Different Depth. J.Fish.Sci. XII (2): 57-63.

[26] Sutaman. 1993. Oyster Pearl: Cultivation Techniques and Process of Making Pearl. Kanisius Publisher. Yogyakarta: 93 Page.

[27] Syda Rao G, Pattnaik P, Dash B. 2009. Growth and biometric relationship of the silver or gold-lip pearl oyster, Pinctada maxima (Jameson, 1901) under landbased culture system. Indian J. Fish. 56 (4): 249-255.

[28] Tomatala P. 2011. The Influence of Temperature on Spawning Pearl ShellPinctada maxima (Jameson). Journal of Tropical Marine and Fisheries.7 (1): 36-38.

[29] Tweddle JF, Simpson JH, Janzen D. 2005. Physical controls of food supply to benthic filter feeders in the Menai Strait, UK. Mar. Ecol. Prog. Ser. 289: 79-88. 
[30] Winanto T. 2009. The Influence of Temperature and Salinity on Physiological Response of Larvae Pearl Shell Pinctada maxima (Jameson). Journal Biology Indonesia. 6 (1): 51-69.

[31] Yukihira H, Klumpp DW, Lucas JS. 1999. Feeding adaptation of the pearl oysters Pinctada margaritifera and $P$. maxima to variations in natural partikulates. Mar Ecol Prog Ser. 182: 161-173.

[32] Yukihira H, Klumpp DW, Lucas JS. 2000. Comparative effects of temperature on suspension feeding and energy budget of the pearl oysters Pinctada margaritifera and P. maxima. Mar Ecol Prog Ser. 195: 179-188. 